\title{
THE UNIVERSITY LIBRARY AS A COMPLEX ADAPTIVE SYSTEM (CAS)
}

\author{
Roberta Moraes de Bem (1) Christianne Coelho de Souza Reinisch Coelho (2) \\ Gertrudes Aparecida Dandolini (3)
}

\begin{abstract}
(1) Universidade Federal de Santa Catarina, roberta.bem@ufsc.br. (2) gertrudes.dandolini@ufsc.br
\end{abstract}
(3) christianne.ccsrc@gmail.com

\begin{abstract}
The paper introduces a theoretical model based on literature review for understanding the University Libraries as Complex Adaptive Systems, introducing a new methodology to deal with these institutions. It is a possibility for University Libraries managers to glimpse the unstable scenario of these institutions. This approach is based on the literature review to identify approaches considering the complexity within the libraries in order to base the construction of a model as a proposal. Although there are approaches that consider the University Library as a complex institution, it attests that this is not considered in its entirety, that is, not all its services and agents are involved, but only focus on some aspects or ser-
\end{abstract}

\section{Introduction}

Our approach suggests considering the University Libraries as complex institutions because they are constantly changing, and methods are necessary to adapt to this feature to ensure its success. The implicit principles and values in holistic school paradigms may represent, at present, an extremely valid and creative proposal for solving the problems that arise in the library administration area (Maciel and Mendonça, 2006).

Therefore, we hold the idea that the University Libraries, by living the variations of the institutions that support them for a variety of reasons (curriculum change, increase in technologies, freshmen and recurrent form of graduates), and dealing with a wide variety of informational content and in different formats, must be managed from the point of view of Complex Adaptive Systems.

"A complex adaptive system consists of a number of components, or agents, interacting with each other according to sets of rules called schemas in such a manner as to improve their behaviour and thus the behaviour of the system which they comprise. In other words, in a complex adaptive system agents interact in a manner that constitutes learning". (Stacey, 1996, p. 2).

Therefore, in order to bring a background to this proposal, we research authors that approach the complexity in dealing with libraries. However, the focus for vices. Besides, the characterization and understanding of the University Library as a Complex Adaptive System is unknown in the literature. The proposal of a model facilitates the understanding and provides the possibility of practical application for characterization of these institutions, University Libraries, as Complex Adaptive Systems, providing different types of knowledge, as well as the strategies and actions necessary to adapt to the ephemeral context in which they operate.

Keywords: University Libraries; Information Science; Knowledge Management; Complexity; Complex Adaptive System.

which the complexity is used as an analytical lens is varied.

\begin{tabular}{l|c}
\hline \multicolumn{1}{c|}{ Author - finality } & $\begin{array}{c}\text { Principles and theoretical } \\
\text { bases } \\
\text { Application }\end{array}$ \\
\hline $\begin{array}{l}\text { Witten et al. (1999) - To de- } \\
\text { velop a software framework } \\
\text { that successfully manage the } \\
\text { complexity (collections and } \\
\text { indexes update, multiple lan- } \\
\text { guages, different versions, } \\
\text { multimedia collections, dif- } \\
\text { ferent search source and user } \\
\text { profiles, creating new collec- } \\
\text { tions etc.) in digital libraries. }\end{array}$ & $\begin{array}{l}\text { Digital libraries; } \\
\text { Somplexity management; }\end{array}$ \\
\hline $\begin{array}{l}\text { Parnell (2002) - To discuss } \\
\text { the role of complexity in the } \\
\text { work of libraries to support } \\
\text { the distance learning. }\end{array}$ & $\begin{array}{c}\text { Distance learning; } \\
\text { Costs. }\end{array}$ \\
\hline $\begin{array}{l}\text { Dresang (2006) - To approach } \\
\text { the complexity relating to } \\
\text { intellectual freedom. }\end{array}$ & \begin{tabular}{c} 
Intellectual freedom; \\
Digital society. \\
\hline
\end{tabular} \\
\hline
\end{tabular}




\begin{tabular}{|c|c|}
\hline $\begin{array}{l}\text { Kauffman }(2007)-\text { To talk } \\
\text { about the complexity of to- } \\
\text { day's world, characterized by } \\
\text { digital information and GC in } \\
\text { contrast to traditional collec- } \\
\text { tions. }\end{array}$ & $\begin{array}{l}\text { Digital information; } \\
\text { University Libraries. } \\
\text { UNIVERSITY } \\
\text { LIBRARIES }\end{array}$ \\
\hline $\begin{array}{l}\text { Gilstrap (2009) - To approach } \\
\text { the theoretical principles and } \\
\text { research on leadership and } \\
\text { management approaches that } \\
\text { have shaped the thoughts } \\
\text { about how to manage and } \\
\text { lead libraries. Based on be- } \\
\text { havior, cognition, systems } \\
\text { and complexity theories. }\end{array}$ & $\begin{array}{l}\text { Behavior; } \\
\text { Cognitive theories; } \\
\text { Leadership; } \\
\text { Organizational develop- } \\
\text { ment; } \\
\text { Theories of complexity; } \\
\text { Organizational change. } \\
\text { UNIVERSITY } \\
\text { LIBRARIES }\end{array}$ \\
\hline $\begin{array}{l}\text { Blake and Collins }(2010) \text { - To } \\
\text { demonstrate the complexity in } \\
\text { dealing with electronic jour- } \\
\text { nals, including acquisition, } \\
\text { availability of tools, cost, } \\
\text { management etc. }\end{array}$ & $\begin{array}{l}\text { Electronic Collection } \\
\text { Management. } \\
\text { UNIVERSITY } \\
\text { LIBRARIES }\end{array}$ \\
\hline $\begin{array}{l}\text { Neal (2012) - To discuss the } \\
\text { trend of the role of University } \\
\text { Libraries in the integration of } \\
\text { resources (print and digital), } \\
\text { using a more systemic } \\
\text { scheme(?) relating to collec- } \\
\text { tion and challenges in ser- } \\
\text { vices. }\end{array}$ & $\begin{array}{l}\text { University Libraries; } \\
\text { Post-digital context. }\end{array}$ \\
\hline $\begin{array}{l}\text { Jantz (2012) - To investigate } \\
\text { the role of leaders in the in- } \\
\text { novation process, concluding } \\
\text { that factors as size, complexi- } \\
\text { ty and environmental factors } \\
\text { are largely responsible for } \\
\text { innovation in University Li- } \\
\text { braries. }\end{array}$ & $\begin{array}{l}\text { Leadership styles; } \\
\text { Organizational change; } \\
\text { Innovation; } \\
\text { Complexity. } \\
\quad \text { UNIVERSITY } \\
\text { LIBRARIES }\end{array}$ \\
\hline $\begin{array}{l}\text { Magi and Mardeusz (2013) - } \\
\text { To explore the complexity of } \\
\text { the individual service to users } \\
\text { (reference service). }\end{array}$ & $\begin{array}{l}\text { Reference service. } \\
\text { UNIVERSITY } \\
\text { LIBRARIES }\end{array}$ \\
\hline
\end{tabular}

Table 1 - Libraries and Complexity

Source: Bem (2015, pp. 150-152).

Looking at the information in Table 1 we found that the studies discuss the complexity superficially, not approaching it as a worldview or as a feature of a system/organization, but just as a feature of some specific aspect. The main recurrence was associated with the digital context, highlighting the difficulty of coexistence of print and digital collections.

From the literature on complexity applied to libraries, we can say that the studies are incipient and do not approach the view of CASs, University Libraries and neither general libraries.

However, leadership, management and administrative theories have received a greater focus of attention in libraries area, especially because of all the changes and innovations of the Information and Knowledge Society.
To consider the Complexity Theory and CASs, aspects such as leadership, for example, are extremely important because the leaders play a key role in the group's effectiveness and organization (Cassanego Júnior, 2008).

Throughout these lines, we believe that the approach on Complex Adaptive Systems is adequate to understand the change in these institutions. Especially from the perspective of librarians, as they have entered a turbulent period and perhaps chaotic in their profession. The Complexity Theory may help explain, more naturally and focused on the human form way, how complex phenomena emerge and cause changes in University Libraries.

Using CAS as a way of managing the University Library means that we believe in a form of management focused on people, which corroborates the principles of the Information and Knowledge Society. In the vision of Complexity, these people are called agents. Then, following Axelrod and Cohen (1999) guidelines, means that it is necessary to know the relationships of these agents (interaction), their strategies and tools (artifacts) used to develop their work causing changes (variation) that lead to improvement and adaptation (selection). However, the literature is scarce in providing methodologies and proposals to manage the libraries from this perspective.

Throughout this work, we intend to answer the following question: "How to design University Libraries as Complex Adaptive Systems?" Therefore, we propose a methodology based on Axelrod and Conhen (1999), which consider the University Libraries as Complex Adaptive Systems, providing the manager/leader innovative ways to deal with the complexity feature of these institutions.

\section{Literature review}

\subsection{University Libraries}

Despite the globalization of information and the World Wide Web, which provided quick access to information regardless of where we are; libraries remain alive to this day. However, these changes characterize new concepts, models and functions for libraries that attend a content that grows and proliferates every day.

In considering the University Libraries, these modifications are even more apparent because they are subject to change conditions and other characteristics of the institutions that support them, these modifications should always follow the reflections of its provider, the university. These characteristics make them metamorphic institutions that need to overcome challenges created by significant changes in their functions (Carvalho, 2004).

Libraries have reflected numerous changes due to a variety of aspects - physical spaces that evolve into 
learning spaces; librarians that interact with advanced web 2.0 source; complexity in the way of researching and creating knowledge; digital resources constantly expanding $\mathrm{x}$ printed collections; environments in which they operate - breaking paradigms and historical traditions of the University Libraries (Gilstrap, 2009).

Che Rusuli et al. (2012) believe that University Libraries need to change their ways using a number of strategies. The way to attend and manage these institutions can be a good alternative according to Porumbeanu (2009), so that libraries can survive in a global economy. To have important people in market knowledge these institutions must continually redesign their management systems.

\subsection{Complexity theory and Complex Adaptive Systems}

Analyzing the organizational context in which we are working, the Complex Adaptive Systems (CAS) as part of the Complexity Theory, brings important contributions once they [...] have the property of aggregating forming new agents at a higher level, as well as they were formed by the aggregation of individuals at a lower level. This property gives greater chance of adaptability and survival as it increases the degree of organization where the system is (Savi et al., 2005).

A Complex Adaptive System consists of a number of components (or agents) interacting with each other according to a set of rules called scheme, in order to improve performance, and improve system performance by comprising them, i.e., they interact to imply a learning process (Stacey, 1996).

In order to determine CAS characteristics, one of these components, adaptive agents, may become the first step. The main feature of certain agent is that he/she changes his/her behavior over time, depending on the learning he/she has from the experience. This feature makes the Adaptive System complex, with more than one agent (Holland, 2008).

In addition to the agents, the Adaptive Complex Systems have several elements that need to be respected for the understanding. Axelrod and Cohen (1999) bring some concepts that are key to understand this approach:

a) Agents - elements that have the ability to interact with their environment, including other agents. Agents are characterized by three attributes: location (where the agent operates), capacities (how the agent can affect the world) and memory (what prints the agent can bring from his/her past);

b) strategy - the way the agent reacts to his/her environment and pursues his/her objectives;

c) population - the population agents are important in three ways: as a source of possibilities to learn, as containers for a newly discovered improvement, and as part of their environment;

d) Artifacts - objects that are used by agents may have important properties as location or capabilities. However, artifacts usually do not have their own goals or powers of reproduction;

e) System - indicates one or more populations of agents, all the strategies of all agents and the relevant artifacts and environmental factors;

f) Selection - are changes in agents and their strategies, it is the result of mechanisms such as learning by trial and error, or the imitation of agents' strategies apparently successful. It may also result from population changes as birth and death, hiring and firing, immigration and emigration or opening and bankruptcy. The selection is not necessarily beneficial, and these are processes that lead to an increase or decrease in the frequency of various types of agents or strategies;

g) Adaptation - selection process, which leads to improvement, according to some measure of success;

h) Co-evolutionary process - multiple populations of agents are adapting to each other;

i) Variation - changes processes, provides the feedstock for adaptation;

j) Interaction - relation. Proximity factors determine how the agents are able to interact with each other. Activation factors determine the sequencing of the activity. The interaction patterns are recurring contact regularities between types within a system;

k) Type - category of agents within a population;

1) Space:

- physical space - geographical time and space localization of agents and artifacts;

- conceptual space - "location" in a set of structured categories so that "near agents " tend to interact;

- digital space - as a way to update the element space, we decided to include a third type of space due to the quantity of resources and services that are held and processed in the digital space, in this context, understood as the place that supports the storage of information, knowledge, documents, relationships, services and others.

m) Success criteria or performance measure - a "score" used by an agent or designer to assign 
credit in strategies to select relatively successful (or unsuccessful) agents.

Thus, the methodology proposal presented in this paper is to show how and why it is important to make use of these elements (agents, selection, variation, etc.) in the management of a Complex Adaptive System. In this case, we consider the University Library.

\section{University Library as a Complex Adaptive System}

The application of the Adaptive Complex Systems approach in the context of University Libraries required the specification of the agents, what they can see and do, how they generate variety in their behavior, how they interact with each other and how the agents and their strategies are selected for preservation, expansion or extinction. Thus, in order to facilitate the understanding of a University Library as a Complex Adaptive System, we developed Figure 1 to represent its agents, populations, strategies and other elements in the different spaces where UBs are present (conceptual, physical and digital/virtual). In Figure 1, five types of agents were exemplified (user, employee, contractor, class entity, partner agent), each one of these types constitutes populations. The agents and their populations interact with their environment, in physical, digital or conceptual spaces, using strategies and artifacts to achieve their goals.

It is from these interactions and relationships that the system adapts as a result of change (variation) and the selection process in order to seek the improvement according to performance measures.

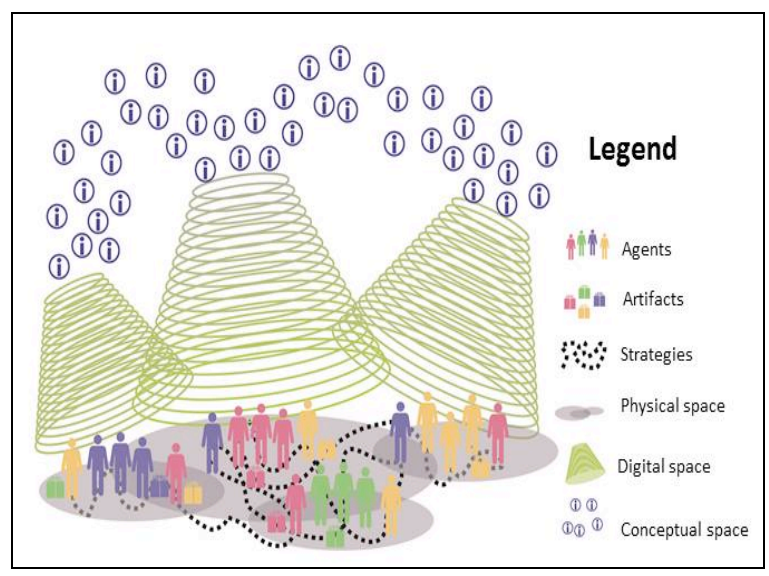

Figure 1 - University Library as a Complex Adaptive System

Source: Bem (2015, p. 174)

Figure 2 focus on aspects of adaptation, interaction and selection, highlighting the instability characteristic of these institutions. An agent connects with other agents (internal or external to the system) and acts based on their knowledge and on a set of multiple rules, criteria and technologies that are the strategies and artifacts. From these interactions and actions, an agent or group of agents can create, copy, select new strategies and artifacts, what can lead to adaptation and evolution of the system (or not - the agents actions can also cause the system to bankruptcy) as a continuous and ongoing process.

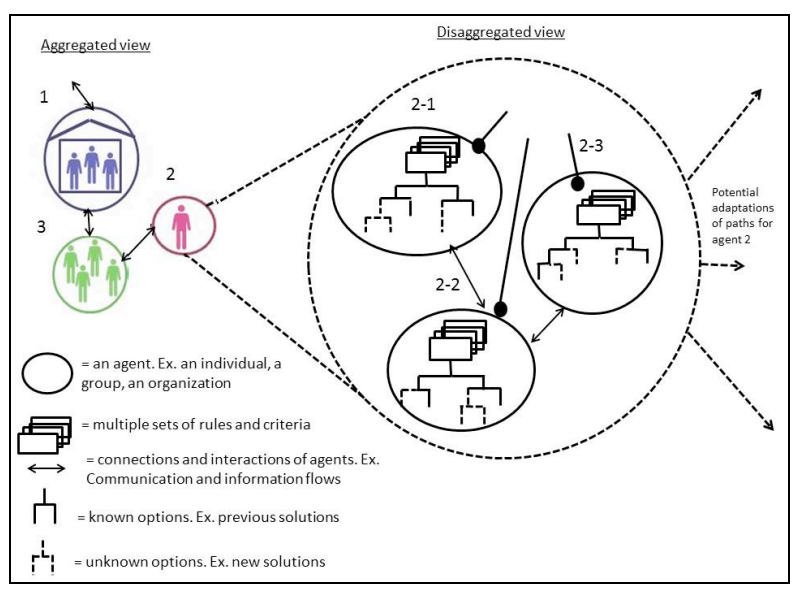

Figure 2- Disaggregated vision of the adaptations, interaction and selections of the University Library as a CAS

Source: Bem (2015, p. 175)

The recommendation of the Complex Adaptive Systems approach is behind the intention to know the complexity in order to understand it, to make it possible to change the structure of a system, to expand some measures of performance, and to know that the system itself is complex. In other words, the idea is to use the knowledge of complexity to make improvements. Expanding the complexity typically means living with it, and taking advantage of it, instead of trying to ignore it or delete it (Axelrod and Cohen, 1999). The relation between exploitation and exploration requires an idea of balance, which tries to improve the use of the existing resources (exploitation) in composition with the exploitation of new knowledge, opportunities, alternatives (exploration).

\subsection{Proposed Model}

The idea is to act in the mechanisms of variation, interaction and selection, focusing on key elements of the University Library, the agents. However, it becomes more difficult in systems extremely subject to change as the UBs. Therefore, we develop verification guidelines, which should guide the University Library in its characterization as a Complex Adaptive System, focusing on recognition (Table 2 ), its variation process (Table 3), interaction (Table 4) and selection (Table 5). The proposal is based mainly on Axelrod and Cohen (1999) questions. These questions present a plan for the user who wants to manage complexity in his/her system, helping them to lead in the field of complexity of a particular system, but they attempt to translate and adapt to the reality of University Libraries with more 
usual expressions and examples associated to the practice.

\subsubsection{Recognition}

It is important that the University Library can be recognized, and the agents represent key elements in this task, including all their attributes, because they correspond to the main element of the institution. The library can create its own symbols to organize their agents' information as well as their strategies and processes, or even make these representations in the form of pictures or diagrams as it prefers (see Figure 3 in Appendix). Therefore, in Table 2 we present the developed guidelines, with some examples of what or who are related (see Appendix).

\subsubsection{Variation}

These seven guidelines will assist not only in recognition of UL, but will also guide managers in the adaptation of strategic planning and decision-making processes for future actions of UL.

\begin{tabular}{l} 
Verification criteria \\
(The University Library...) \\
\hline 1. Must be aware of the changes that happen in recent \\
times. \\
Particularly in relation to: staff; user (profile, number); \\
physical space; technologies. \\
\hline 2. Knows based on identified changes. \\
Examples: \\
Others institutions/Rules/law/Users/Providers/Internal \\
demands. \\
\hline 3. Must be aware of new technologies that offer new pos- \\
sibilities in generating variety. \\
Example: creation of new services using QR Code. \\
\hline 4. Identifies how errors occur in current processes \\
\hline 5. Can realize if the occurring changes are generating \\
benefits or not. \\
\hline 6. Must be aware what is the right balance between varie- \\
ty and uniformity (standard services x innovative ser- \\
vices) inside the system.- \\
Example: physical loans x e-books downloads \\
\hline 7. Knows whether the exploration is especially valuable \\
because improvements can be widely applied and/or used \\
over a long period. Inversely, it knows if there is a disas- \\
ter risk by trying a bad strategy. Ex.: open the UB 24 \\
hours a day. \\
\hline
\end{tabular}

Table 3 - Verification criteria for knowledge and control of the variation

Source: Bem (2015, pp. 213-213)

One way to balance the exploration and exploitation content worked in organizational learning and that is directly associated with the complexity and especially of CAS - as suggested by Axelrod and Cohen (2002), would be the interaction between the less experienced employees and employees admitted more recently with more experienced employees and those who have been longer in the organization. This principle captures the tension between creation of untested types that can be higher than that currently existing and the copy of types already tested that proved better so far.

\subsubsection{Interaction}

Interaction patterns help determining what will be successful for the agents of a system and this, in turn, helps in interaction patterns dynamic among them. Interaction patterns form the events in which we are directly interested (with changes) and they provide the opportunity to spread and recombine types that are so important in the creation (and destruction) of variety. (Coelho, 2001, p. 101).

The mechanisms that deal with interactions fit conveniently into two classes: external and internal. The external mechanisms are ways to modify system interactions from outside - designing artifacts or planning policies that change the rules by which others play, for example. The internal mechanisms are ways to change the interaction patterns that are induced by processes within the system. (Axelrod and Cohen, 1999).

As well as the variation must balance between exploitation and exploration, interaction patterns must also follow a uniformity among intense interactions - when interactions usually are the same, with the same agents and strategies - and diffuse systems - where the turnover between agents and interaction patterns are too large, causing insufficient exploitation and the lack of variety (Axelrod and Cohen, 1999). Table 4 shows verification criteria developed for understanding interaction patterns, some examples and what or who is related.

Verification criteria
(The University Library...)

1. Has mapped the main forms of interactions among the agents (How? Where? Who?).

2. Knows what influence certain interactions. Examples: hierarchical relationships, bonds of friendship, physical proximity

3. Identifies what interventions could change patterns of interaction (so that they could be useful for the whole system). Knows possible physical or conceptual neighborhoods of interaction it needs to help form, or that deserves to be interrupted.

Examples:

$\checkmark$ Establishing physical barriers (screens) to break the flow of interactions;

$\checkmark$ Creating practice communities (conceptual space) to provide interaction among certain agents;

$\checkmark$ Function rotation systems and workstation on a certain day of the week or month so that colleagues can understand how their activities impact on the work of others.

Table 4 - Verification criteria for understanding the interaction patterns

Source: Bem (2015, pp. 214-215) 
The complexity is often rooted in patterns of interaction among the agents, then we can expect that systems exhibit increasingly complex dynamic when that enhance changes the interaction among elements. When they interact, they are co-located, or interact via technology, which is self- located. Thus, we can also say that the interactions are located (Axelrod and Cohen, 1999).

The interactions need to be monitored to improve the system, so the factors of proximity - how the agents interact (physical space, hierarchy, friendship links etc.) and activation - processes grouping that affect the timing of agent- are required to be known and used for the benefit of CAS (Axelrod and Cohen, 1999). Thus, the manager can use mechanisms that increase, decrease or modify the patterns of interaction, which is important for Knowledge Management.

\subsubsection{Selection}

When a selection process leads to success, then we call it adaptation (Axelrod and Cohen, 1999). Based on adaptation, we will work the issue of selection, always searching for continuous improvement. Therefore, we must be based on verification criteria exposed in Table 5 so that it can guide the selection for adaptation.

\section{VERIFICATION CRITERIA}

(The University Library...)

1. Defines the success criteria used to select the initiatives that become more (or less) common over time. Identifying changes that lead to adaptation or not.

2. Recognizes best practices that can be listed and actions that may be taken as learning for the future (lessons learned).

3. Knows the tools that may represent measures of success. Examples: university rankings, results of user studies, loan numbers/access/visits etc.

Table 5 - Verification criteria to conduct the selection

Source: Bem (2015, p. 216), based on Axelrod and Cohen (1999)

The analysis and control of the four proposed elements (agents, variation, interaction, selection) must be directly associated to all activities of the University Library, especially the management. Instead of weakening the value of complexity as a way to think about social systems, an appreciation of how Adaptive Complex Systems can fail provides valuable guidance for the planning and management of complex systems, including human organizations, as well as technical systems. Planning new strategies and organizations often involves modifying - or even creating - the variation, interaction and selection, hallmarks of a Complex Adaptive System (Axelrod and Cohen, 1999).

\section{Conclusions}

The proposal to suggest a methodology able to understand the University Libraries as Adaptive Complex Systems can help managers in various aspects, considering that it works essential elements for the coordination of a library. Instead of suggesting books or information, we suggest people; this is the focus of the University Library, its user (agent). The methodology presented puts the human element as principal target of the methodology, influencing and being influenced by other elements (variation, interaction and selection).

Thus, the manager has a tangible tool to work, despite having complex and robust theory; he overcomes abstraction capability that the theme suggests. We believe we can see other studies in this area, based on or from this, including its practical application, what may result in adjustments and improvements of the proposed methodology.

According to Axelrod and Cohen (1999) - by associating the information to the complexity and adaptation in the Information Revolution - there are deep limits in our ability to predict what is to come. A cautious attitude related to forecast is probably healthy, but it presents a difficult barrier to the normal process of designing new artifacts or strategies, or the refinement and implementation of policies. Therefore, The Libraries need to worry about equalizing exploration and exploitation initiatives, and to have allies to help them, in order to verify the validity of each industry, analyzing risks, measures of success, and others.

For Pacheco et al. (2005), despite the view of the Complexity of human being requires a renovation of thought, it is clear that the solution is something that will extend to the future. Because of great transformations the world has been suffering today, due to the volume of information available and free access, it is necessary that the management models accelerate their understanding of human behavior in organizations and established social networks and consequent interrelations of cause and effect, characteristics of complex organizations. Likewise, we believe that the majority of this task, to manage organizations and find new ways to control and understand the Complexity, seems to fit to the research, starting with the realignment of the management models. Therefore, we chose the Complexity Theory, but specifically the Complex Adaptive Systems, as a way of looking the University Libraries, with the intention of contributing to the development of new knowledge and provision of tools to assist these institutions susceptible to interpellations of the environment and context in which they operate.

\section{References}

Axelrod, R. M.; Cohen, M. D. (1999). Harnessing complexity: organizational implications of a scientific frontier. The Free Press: New York, 1999. 
Bem, R. M. de. (2015). Framework de gestão do conhecimento para bibliotecas universitárias. Doctoral thesis. http://tede.ufsc.br/teses/PEGC0364-T.pdf (2016-01-05).

Blake, K.; Collins, M. Controlling chaos: management of electronic journal holdings in an academic library environment. // Electronic Journal Forum. 36: 4 (December 2010) 242-250. http://dx.doi.org/10.1016/j.serrev.2010.08.015 (2013-08-14).

Carvalho, I. C. L. (2004). A socialização do conhecimento no espaço das bibliotecas universitárias. Niterói: Intertexto; Rio de Janeiro: Interciência, 2004.

Cassanego Júnior, P. V. (2008) Complexidade e organizações: a dinâmica dos sistemas adaptativos complexos // Wittmann, M. L. (org.). Administração: teoria sistêmica e complexidade. Santa Maria, Ed. UFSM, 2008. 85-98.

Che Rusuli, M. S.; Tasmin, R.; Takala, J. (2012). The impact of structural approach on knowledge management practice (KMP) at Malaysian University Libraries. // Australian Journal of Basic and Applied Sciences. 6:10 (2012) 122-128. http://www.ajbasweb.com/ajbas/2012/October/122-128.pdf (2013-04-25).

Coelho, C. de S. R. (2001). Complexidade e sustentabilidade nas organizações. Doctoral thesis. http://www.tede.ufsc.br/teses/PEPS1753-T.pdf (2013-07-26).

Dresang, E. T. (2006). Intellectual freedom and libraries: complexity and change in the twenty-first-century digital environment. // Library Quarterly. 76: 2 (2006) 169-192. http://courseweb.lis.illinois.edu/ katewill/spring2011$502 / 502 \% 20$ and $\% 20$ other\%20readings/dresang\%202006\%20i ntell\%20freedom\%20libraries.pdf (2013-08-14).

Gilstrap, D. L. (2009). A Complex Systems Framework for Research on Leadership and Organizational Dynamics in Academic Libraries. // Portal: Libraries and the Academy. 9:1 (January 2009) 55-77. http://dx.doi.org/10.1353/pla.0.0026 (2013-0618).

Holland, J. (2008). Sistemas complexos adaptativos e algoritmos genéticos. // Nussenzveig, H. M. (org.). Complexidade e caos. 3rd. Rio de Janeiro: Ed. UFRJ, 2008. 213-230.

Jantz, R. C. (2012). Innovation in academic libraries: an analysis of university librarian's perspectives. // Library \& Information Science Research, 34 (January 2012) 3-12. http://dx.doi.org/10.1016/j.lisr.2011.07.008. (2013-06-18).

Kauffman, P. (2007). It's not your parents' library anymore: challenges and opportunities in the new webs of complexity. // Journal of Library Administration. 46:1 (2007) 5-26. http://dx.doi.org/10.1300/J111v46n01_02 (2013-08-14).

Maciel, A. C.; Mendonça, M. A. R. (2006). Bibliotecas como organizações. Rio de Janeiro: Interciência; Niterói: Contexto, 2006.
Magi, T. J.; Mardeusz, P. E. (2013). What students need from reference librarians: exploring the complexity of the individual consultation. // College \& Research Libraries News. 74:6 (June 2013) 288-291. http://crln.acrl.org/content/74/6/288.full (2013-08-13).

Neal, J. G. (2012). Opportunities for systematic change in the academic research library: elements of the post-digital library. //

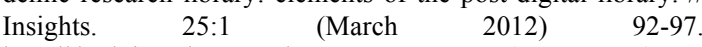
http://dx.doi.org/10.1629/2048-7754.25.1.92 (2013-08-14).

Pacheco, A. P. R; Salles, B. W.; Garcia, M. A.; Possamai, O. (2005) O ciclo PDCA na gestão do conhecimento: uma abordagem sistêmica. (2005) http://www.isssbrasil.usp.br/isssbrasil/pdfs2/ana.pdf (2013-1110).

Parnell, S. (2002). Redefining the cost and complexity of library services for open and distance learning. // International Review of Research in Open and Distance Learning. 3:2 (October 2002) 188-204 http://www.irrodl.org/index.php/irrodl/article/view/102/181(20 13-08-13)

Porumbeanu, O. L. (2009). Strategic model for implementing knowledge management in libraries or information services. // Library \& Information Science Research. 13 (2009) 89-105. http://search.ebscohost.com/login.aspx?direct=true\&db=lih\& AN=47272043\&lang=pt-br\&site=ehost-live (2013-05-03).

Savi, A. E.; Sehnen, S.; Erdmann, R. H. (2005). Abordagens alusivas à teoria da complexidade. // Contexto e Educação. 20:73/74 (January 2005) 9-40. https://www.revistas.unijui.edu.br/index.php/contextoeducaca o/article/view/1119 (2013-07-24).

Stacey, R. (1996). Emerging Strategies for a Chaotic Environment. // Long Range Planning. 29:2 (April 1996) 182-189. $\mathrm{http}: / / \mathrm{dx}$.doi.org.ez46.periodicos.capes.gov.br/10.1016/00246301(96)00006-4 (2014-04-02).

Witten, I. H. et al. (1999). Managing Complexity in a Distributed Digital Library. // Computer. 32:2 (February 1992) 74-79. http://dx.doi.org/10.1109/2.745723 (2013-06-18).

Copyright: (C) 2017. Bem et al. This is an open-access article distributed under the terms of the Creative Commons CC Attribution-ShareAlike (CC BY-SA), which permits use, distribution, and reproduction in any medium, under the identical terms, and provided the original author and source are credited.

Received: 2015-11-18. Accepted: 2016-08-2 


\section{Appendix}

Figure 3

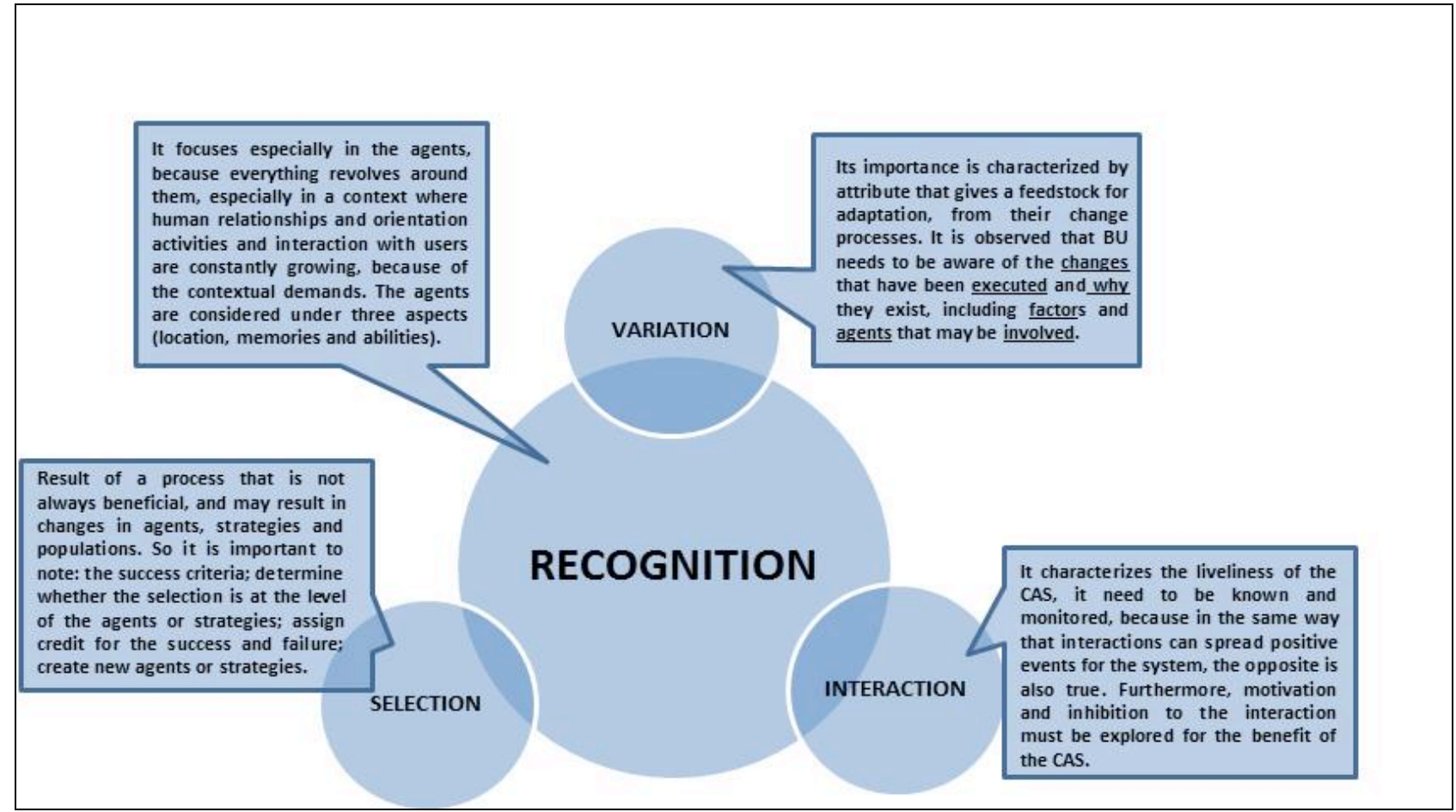

Figure 3: - Pillars of Complex Adaptive Systems

Source: developed by the authors (2017) 
Table 2

Verification criteria

(The University Library...)

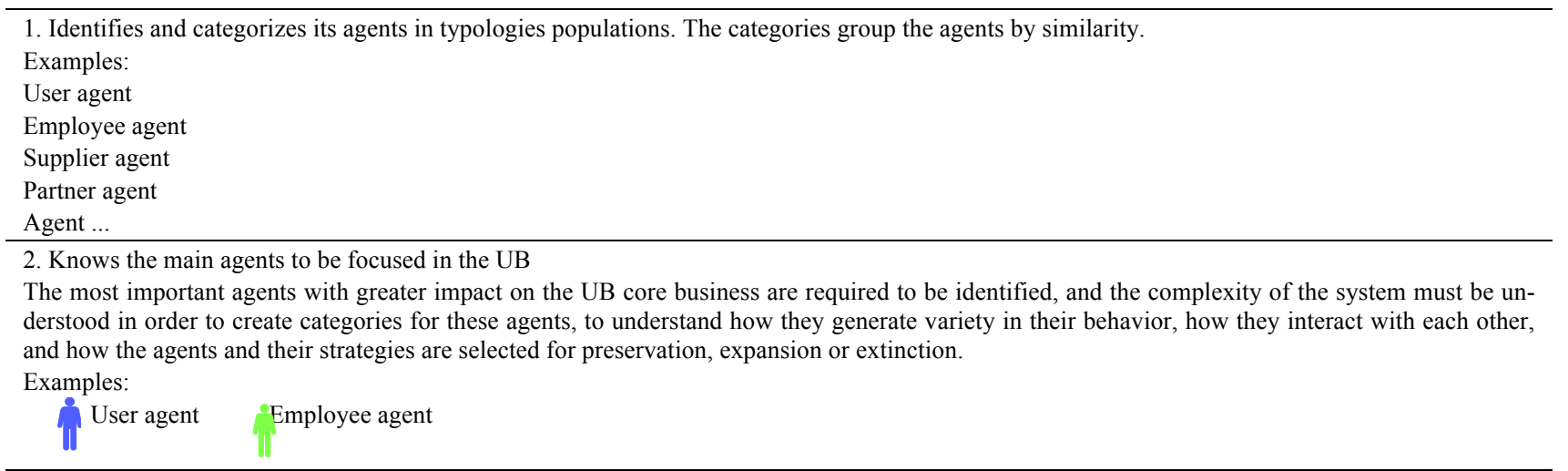

3. Identifies the main strategies, and ideas, rules, routines and standards used by the agents to act.

It is important to remember that all these aspects must be raised together with the team, i.e., the agents themselves.

Examples:

$4 \times$ Collection development policy

Service strategy

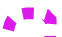

Strategy to pass knowledge

4. Has mapped its processes

If the UB does not have the process mapping (set of activities to achieve a service) established formally, it is required to be developed. From the mapping of UB's key processes we can identify, among other things, strengths and weaknesses, knowledge and agents involved, the level of complexity of the operation.

Examples:

$\checkmark$ To develop/update the Collection Development policy;

$\checkmark$ To manage journal portal;

$\checkmark$ To perform reference service;

$\checkmark$ To perform user studies;

$\checkmark$ To generate statistical reports;

$\checkmark$ To promote acquisition (purchase, exchange and donation);

$\checkmark$ To perform disposal and relocation;

$\checkmark \quad$ To take on loan.

5. Knows the classifications that the agents themselves make of other agents in populations and types.

Some classifications are necessary to understand that there are different needs among the agents, in the case of UB, users constitute in a good application.

Examples:

$\checkmark$ inconvenient user ((one who insistently calls the library demanding services that it does not offer (extend the opening hours for specific purposes or normalize academic papers));

$\checkmark$ freshman user (basic demands as loan information);

$\checkmark \quad$ infrastructure user (use the library only as physical space);

$\checkmark \quad$ elite user (specific and difficult questions to be answered, requiring a highly qualified professional and expending a lot of time with this).

6. Should be aware of the artifacts, resources, and tools used by agents to execute its strategies.

Examples:

Furniture (table, chairs, bookcases, filing cabinet, folders, projector etc.);

Information artifacts (books, journals, papers, academic papers etc.);

Tools like the internet and computer (catalogs, databases, bibliographic managers, metasearchers, discovery tools, various software);

Computers and similar;

Knowledge sharing resources (cataloging, collection etc.).

7. Defines the physical, conceptual and digital spaces where agents act.

Examples:

$\checkmark$ Physical space: to enter information as film, plans, location, photos etc.;

$\checkmark$ Conceptual space: to insert chart, communities of practice, working groups etc.

$\checkmark \quad$ Digital space: web pages, portals, e-mail, chat, social network etc.

Table 2 - Verification criteria for recognition of the University Library

Source: Bem (2015, pp. 209-211)

Bem, Roberta Moraes de; Coelho, Christianne Reinisch de Souza Coelho; Dandolini, Gertrudes Aparecida. The University Library as a Complex Adaptive System (CAS) // Brazilian Journal of Information Studies: Research Trends. 11:2 (2017) p.19-27. ISSN 1981-1640. 